\title{
PENGEMBANGAN POS PENYULUHAN DESA: Studi Eksperensial Posluhdes di Desa Pattallassang, Kecamatan Tompobulu, Kabupaten Bantaeng
}

\author{
The Post of Rural Extention Development: \\ Experensial Study the Post of Rural Extension in Pattallassang Village, \\ Tompobulu Sub-district, Bantaeng District
}

\author{
Muh. Hatta Jamil ${ }^{*}$, Rusli M. Rukka, A. Nixia Tenriawaru, Dewi Trisnawati \\ Program Studi Agribisnis, Departemen Sosial Ekonomi Pertanian, \\ Fakultas Pertanian, Universitas Hasanuddin, Makassar \\ *Kontak penulis: hatta-jamil@agri.unhas.ac.id
}

\begin{abstract}
This research was taking in Pattallassang Village, Tompobulu Sub-distric, Bantaeng District with agrosystem case that is the act of growing and reinforcement the Post of Rural Extention (Posluhdes). The aim of this research to analyze the problem, target and the action to the act of growing and reinforcement of the Posluhdes in The Pattallassang Village, Tompobulu Subdistricy, Bantaeng District. This research used participatory action research method, the researcher activly involve with the informan to comprehend the situation, identify the problem, decide the target and formulate the actions that will take by the board of the Posluhdes. The result of the research showed the primary problems that deal the Posluhdes organitation not working appropriate by the functions yet. This main problem because there are some farmers still push Posluhdes, there is not administration equipment yet, the structure of organization is not represent all of the commodity, and there are not all of the parmers activly invlove in the formulation process of vision and mission. This main problems effecting that the Extentions program in village level is not yet. Based on the problems faced, then formulated the act of development the Posluhdes that is doing sosialitation, increase the tool and infrastructure, prepare operational budget to the organitation, evolving structure and doing sosialitation vision and mission Posluhdes.
\end{abstract}

Keywords: post rural extension; development.

Sitasi: Jamil, M.H., R.M. Rukka, A.N. Tenriawaru, D. Trisnawati. 2018. Penumbuhan dan Penguatan Pos Penyuluhan Desa, JSEP 14(2): 171 - 182.

\section{Pendahuluan}

Keberadaan kelembagaan penyuluhan pertanian tidak lepas dari peranan pemerintah sebagai penentu kebijakan. Salah satu dukungan pemerintah terhadap keberadaan kelembagaan penyuluhan dapat dilihat dalam Undang-Undang No. 16 Tahun 2006, tentang Sistem Penyuluhan Pertanian, Perikanan dan Kehutanan. Dalam Undang-Undang tersebut diatur bahwa kelembagaan penyuluhan pemerintah terdiri atas Badan Penyuluhan di tingkat pusat, Badan Koordinasi Penyuluhan di tingkat 
provinsi, Badan Pelaksana Penyuluhan di tingkat kabupaten/kota, Balai Penyuluhan di tingkat kecamatan dan Pos Penyuluhan Desa (Posluhdes) di tingkat desa/kelurahan. Kelembagaan penyuluhan pertanian baik di pusat maupun di daerah, harus mampu memfasilitasi petani dan pelaku usaha pertanian lainnya dalam mengembangkan usahanya untuk meningkatkan produktivitas dan pendapatan pelaku utama dan pelaku usaha. Fungsi utama dari kelembagaan penyuluhan pertanian adalah sebagai wadah dan organisasi pengembangan sumberdaya manusia pertanian serta menyelenggarakan penyuluhan pada masing-masing wilayah kerja penyuluhan.

Posluhdes memiliki peran yang strategis untuk kemajuan pembangunan pertanian di pedesaan, peran tersebut salah satu diantaranya memudahkan penyuluh dalam menginventarisir permasalahan petani di lapangan, proses interaksi petani dengan penyuluh di Posluhdes akan berujung pada inventarisasi permasalahan petani oleh penyuluh. Posluhdes tidak hanya sebagai tempat bertemunya petani dan penyuluh, tapi di Posluhdes tersedia berbagai informasi tentang pertanian, seperti informasi dari media Sinar Tani, buku-buku pertanian, folder, brosur dan media penyuluhan lainnya. Dengan adanya media tersebut, petani akan mendapatkan gambaran dan menginspirasinya untuk mempertanyakan masalah yang dihadapinya.

Tujuan Pembentukan Posluhdes adalah untuk mempermudah dan memperlancar penyampaian informasi teknologi kepada petani, agar petani lebih proaktif dalam mencari teknologi dan informasi pertanian secara umum. Disamping itu, merangsang petani, kontak tani dan kelompok tani dalam berkarya dan menemukan teknologi baru yang merupakan hasil karya petani sendiri. Sebagai basis kegiatan penyuluhan pertanian di desa, Posluhdes merupakan pos koordinasi, konsultasi dan sinkronisasi seluruh kegiatan yang terkait dengan penyuluhan, serta sebagai sumber informasi dan tempat konsultasi bagi petani/kontak tani melakukan kunjungan ke kelompok tani di lapangan (Bapelluh Cilacap, 2015).

Pos penyuluhan desa/Posuluhdes adalah kelembagaan penyuluhan pada tingkat desa yang bersifat non struktural yang dibentuk dan dikelola secara partisipatif oleh pelaku utama, sebagai tempat pertemuan para penyuluh, pelaku utama dan pelaku usahal. Pos penyuluhan desa ini dibentuk dan dikebangkan dengan pronsip partisipatif, keswadyaan, demokratis, desentralisasi, keterbukaan, sensitif gender, keserasian, kepempinan dari petani, kesetaraan dan kemitraan (Marwati, 2015). Selanjutnya disebutkan fungsi Posuluhdes adalah Menyusun programa penyuluhan ditingkat desa, Melaksanakan penyuluhan di desa; Menginventarisir permaslahan dan pemecahannya; Melaksanakan proses pembelajaran melalui percontohan dan pengembangan model usaha tani bagi pelaku utama dan pelaku usaha; Menumbuh kembangkan kepemimpinan, kewirausahaan, kelembagaan pelaku utama dan pelaku usaha; Melaksanakan kegiatan rembug, pertemuan teknis temu lapang dan metoda penyuluhan lain bagi pelaku utama dan pelaku usaha; Memfasilitasi layanan informasi, konsultasi, pendidikan, serta pelatihan bagi pelaku utama dan pelaku usaha, dan Memfasilitasi forum penyuluhan perdesaan (Marwati, 2015).

Studi tentang Pos Penyuluhan Desa masih sangat sedikit yang dilakukan. Di Sulawesi Selatan, hanya ditemukan satu studi mengenai Pos Penyuluhan Desa yang dilakukan oleh Pratiwi dkk., (2018) yang meneliti pelaksanaan program penyuluhan 
Pertanian di Pos Penyuluhan Desa Layoa, Kecamatan Gantarang Keke, Kabupaten Bantaeng. Dalam kaitan itu, menjadi imperatif untuk meneliti tentang bagaimana permasalahan dalam pengembangan Pos Penyuluhan Desa.

Pentingnya meneliti pengembangan Pos Penyuluah Desa ini bermula dari kegiatan pengabdian pada masyarakat melalui Ipteks bagi Masyarakat (IbM) Tahun 2016 dengan judul "IbM Penguatan Kapasitas Kelembagaan Penyuluhan melalui Posluhdes pada BP3K Dampang dan Tompobulu di Kabupaten Bantaeng, Sulawesi Selatan". Dalam kegiatan tersebut berhasil dibentuk dua Posluhdes masing-masing Posluhdes Tombolo di Kecamatan Gantarangkeke/BP3K Dampang dan Posluhdes Pattallassang di Kecamatan Tompobulu/BP3K Tompobulu. Permasalahan utama yang dihadapi oleh masyarakat berdasarkan identifikasi awal pada kegiatan tersebut adalah pemahaman masyarakat di setiap desa yang menjadi lokasi terhadap fungsi dan peran Posluhdes terbilang sangat minim. Olehnya itu, melalui kegiatan IbM 2016 tersebut, telah dilakukan sosialisasi terkait fungsi dan peran Posluhdes dan seluruh pemangku kepentingan terutama pengurus kelembagaan di tingkat petani dan tenaga penyuluh yang ada di masing-masing wilayah desa dan setelah mereka memahami selanjutnya menyepakati terbentuknya Posluhdes di wilayah tersebut.

Menindaklanjuti hasil kegiatan tersebut, maka dilakukan penelitian dengan tujuan mengidentifikasi permasalahan yang dihadapi oleh Posluhdes, merumuskan tindakantindakan dalam rangka penumbuhan dan penguatan Posludes. Dalam penelitian ini beberapa sasaran yang ingin dicapai terdiri dari: 1) Aspek pengetahuan, untuk menambah pengetahuan tentang proses penumbuhan dan penguatan Posludes, 2) Aspek keterampilan, agar mampu dan terampil dalam mengidentifikasi masalah, pemecahan masalah serta mengidentifikasi tindakan pencegahan masalah dalam proses penumbuhan dan penguatan Posluhdes; dan 3) Aspek sikap, agar mampu menghargai pikiran dan tindakan-tindakan yang dilakukan oleh pihak yang terlibat dalam pembentukan Posludes serta dapat memetik hikmah sebagai suatu proses pembelajaran.

\section{Metode Penelitian}

Penelitian ini dilaksanakan di Desa Pattallassang, Kecamatan Tompobulu, Kabupaten Bantaeng, Provinsi Sulawesi Selatan. Metode penelitian yang digunakan adalah Participatory Action Research (Penelitian Aksi Partisipasi), dimana peneliti dan pihak-pihak dalam Posluhdes turut berpartisipasi dalam seluruh kegiatan yang berlangsung dalam Posluhdes. Peneliti mengambil posisi sebagai 'orang dalam' pada Posluhdes kasus.

Ruang lingkup kasus penelitian ini adalah pengembangan Posluhdes yang terdiri dari kegiatan penumbuhan dan penguatan Posluhdes, meliputi pengetahuan petani terhadap Posluhdes, sikap petani terhadap Posluhdes, partisipasi petani dalam penumbuhan Posluhdes, pembenahan administrasi organisasi, perumusan visi dan misi, pembentukan struktur organisasi, penyusunan AD/ART dan penyusunan programa penyuluhan di tingkat desa. Metode ini secara bersama-sama mengidentifikasi keseluruhan agrosistem kasus, disamping itu metode ini juga 
mengarahkan untuk mengetahui sisi-sisi permasalahan secara mendalam terkait dengan kasus yang dijadikan sebagai objek penelitian dan juga menganalisis pemecahan serta tindakan yang nantinya harus dilakukan untuk pengembangan Posluhdes.

Tahapan-tahapan yang dilakukan pada penelitian ini adalah memahami situasi Posludes kasus, mengidentifikasi permasalahan, merumuskan sasaran dan merumuskan tindakan-tindakan dalam rangka pengembangan Posluhdes kasus. Pemahaman terhadap situsi kasus meliputi penelaahan terhadap posisi sumberdaya yang dimiliki Posluhdes yang meliputi lahan dan bangunan, peralatan dan sumberdaya manusia, serta kinerja yang berlangsung terkait ruang lingkup penelitian. Hasil penelaahan menjadi dasar untuk melakukan identifikasi permasalahan yang selanjutnya dianalisis berdasarkan hubungan sebab-akibat (kausalitas) antar-masalah. Berdasarkan masalah-masalah yang telah diidentifikasi, dirumuskan sasaran-sasaran yang menjadi dasar untuk melaksanakan tindakan-tindakan dalam rangka pemecahan masalahnya.

\section{Hasil dan Pembahasan}

\subsection{Permasalahan Posluhdes}

Terdapat beberapa permasalahan yang dihadapi oleh Posluhdes Pattallassang dalam melaksanakan fungsinya sebagaimana yang diamanahkan dalam UU No. 16 Tahun 2006. Masalah-masalah yang diidentifikasi berdasarkan hasil penelitian sebagaimana tabel kesenjangan yang ditampilkan pada Tabel 1, diuraikan sebagai berikut:

a. Status kepemilikan lahan Posluhdes milik pribadi, Bapak A. Abd. Hafid selaku salah satu inisiator pembentukan Posluhdes yang juga menjabat sebagai Ketua Gapoktan memberikan lahannya untuk dijadikan sebagai lahan sekretariat Posluhdes. Seiring berjalannya waktu ketika nantinya Posluhdes berkembang, maka akan menimbulkan dampak jika lahan yang digunakan merupakan milikan pribadi.

b. Kondisi bangunan Posluhdes kurang terawat dan sekretariat yang sempit, bangunan yang nampak kumuh kurang terawat dan luasan sekitar $8 \times 4 \mathrm{~m}^{2}$ dengan beberapa ruangan yang memiliki fungsi yang berbeda hanya mampu menampung sekitar 20 orang. Jika diadakan pertemuan untuk menjalankan fungsi Posluhdes, sekretariat hanya bisa menampung pengurus yang jumlahnya sebanyak 15 orang, sementara jumlah petani di Desa Pattallassang sebanyak 593 orang.

c. Unit peralatan masih terbatas, sekretariat Posluhdes hanya diidi dengan 2 unit meja dan 35 unit kursi yang merupakan milik Gapoktan. Sehingga bila kegiatan pertemuan antara penyuluh dengan petani dan pelaku usaha, fasilitas ini masih sangat kurang.

d. Sosialisasi penumbuhan Posluhdes kurang baik, setiap dilaksanakan penyampaian informasi terkait dengan penumbuhan Posluhdes oleh pengurus kelompok tani kepada anggotanya masih kurang detail dan tidak jelas.

e. Pengetahuan petani mengenai Posluhdes masih kurang, sebagai akibat dari penyampaian informasi yang kurang detail dan tidak jelas dalam sosialisasi penumbuhan Posluhdes, petani belum mengerti tentang kegiatan dan arah tujuan Posluhdes. 
f. Masih ada petani yang menolak adanya Posluhdes, secara umum sikap petani terhadap Posluhdes sangat baik, hal ini ditunjukkan dengan petani yang menerima mencapai $90 \%$, namun masih terdapat sebesar $10 \%$ petani yang menolak karena kurang paham dan mengerti tentang Posluhdes.

g. Belum adanya upaya sosialisasi penumbuhan secara mandiri, seiring berjalannya waktu Posluhdes hingga saat ini belum melakukan kegiatan atau sosialisasi secara mandiri, karena susahnya untuk mengatur jadwal masing-masing pengurus Posluhdes.

h. Perlengkapan administrasi organisasi posluhdes belum ada, sebagai Posluhdes yang baru dibentuk,beberapa kelengkapan administrasi belum tersedia, seperti pembukuan, stempel, papan nama dan struktur organisasi. Tidak adanya kelengkapan administrasi ini menghambat pengurus untuk menjalankan tugas dan fungsinya.

i. Tidak semua petani yang hadir dan terlibat aktif dalam proses perumusan visi dan misi, Dalam kegiatan perumusan visi dan misi Posluhdes, hanya 10\% dari total 20 orang petani yang aktif mengemukakan pendapatnya, selebihnya terlihat pasif dalam kegiatan tersebut.

j. Visi dan misi belum disosialisasikan, meskipun visi dan misi Posluhdes telah dirumuskan, namun pengurus belum melakukan sosialisasi kepada kelompok tani dan anggotanya. Sulitnya mengatur waktu yang tepat karena berbagai kesibukan petani dalam melaksanakan seluruh aktifitas hariannya, terutama aktifitas di usahataninya.

k. Rendahnya pemahaman petani terhadap visi dan misi Posluhdes, sebagai akibat belum tersosialisasikannya visi dan misi Posluhdes, maka petani masih banyak yang belum memahaminya. Bahkan pemahaman petani terhadap organisasi, tujuan dan fungsi Posluhdes sebagai lembaga baru di tingkat petani masih terbatas.

l. Struktur organisasi Posluhdes tidak mewakili semua komoditi, Struktur organisasi Posluhdes hanya mewakili komoditi utama, yaitu padi, jagung dan nenas. Sementara ada beberapa komoditi yang dapat dikembangkan di Desa Pattallassang, seperti kacang tanah, ubi jalar, singkong, pisang, mangga, rambutan, durian, langsat dan alpukat yang jumlah petaninya juga terbilang besar tidak terwakili dalam organisasi Posluhdes.

m. Posluhdes belum berjalan sesuai fungsinya, Posluhdes yang terbentuk belum mampu menjalankan fungsinya sesuai dengan apa yang ada pada Undang-Undang Nomor 16 Tahun 2006. Belum dilakukannya penyusunan programa penyuluhan di tingkat desa, belum dilaksanakannya penyuluhan desa dan belum adanya fasilitasi forum penyuluhan pedesaan, sebagai salah satu indikator penting dalam menjalankan fungsinya sebagaimana yang diamanahkan.

n. Belum adanya alokasi dana Posluhdes, Sejak terbentuknya Posluhdes pada tanggal 25 November 2016, belum ada alokasi dana yang diperuntukkan untuk mendukung kelancaran kegiatan penyuluhan pada Posluhdes. Keterbatasan dana sebagai kendala menyebabkan pengurus Posluhdes belum mampu melakukan kegiatan secara mandiri. 
o. Belum ada usulan petani untuk mengembangkan komoditi pada struktur organisasi Posluhdes, banyaknya potensi komoditi yang dikembangkan seperti kacang tanah, ubi jalar, singkong, pisang, mangga, rambutan, durian, langsat, dan alpukat yang belum terakomodir di dalam struktur organisasi Posluhdes. Pengurus Posluhdes akan mengakomodir seluruh komoditi sepanjang ada usulan dari petani untuk mengembangkan struktur organisasi.

p. Tingkat pendidikan formal petani relatif rendah, Tingkat pendidikan di Desa Pattallassang dengan golongan tingkat pendidikan tidak tamat SD sebanyak 14,7\%, SLTP sebanyak 20,5\%, SLTA sebanyak 11,44\%, tingkat pendidikan akademi sebanyak $0,52 \%$, dan sarjana sebanyak 1,27\%. Data tersebut menunjukkan bahwa tingkat pendidikan penduduk Desa Pattallassang merata mula tingkat Pendidikan Sekolah Dasar sampai Sarjana. Meskipun persentase penduduk tingkat Pendidikan Sarjana masih rendah.

\subsection{Pohon Masalah}

Berdasarkan identifikasi masalah diketahui bahwa masalah utama pada Posluhdes adalah Posluhdes belum berjalan sesuai dengan fungsinya. Masalah ini disebabkan oleh masih adanya petani yang menolak Posluhdes, perlengkapan administrasi Posluhdes belum ada, struktur organisasi Posluhdes tidak mewakili semua komoditi yang ada di desa, dan tidak semua petani yang hadir terlibat aktif dalam proses perumusan visi dan misi Posluhdes. Masalah masih adanya petani yang menolak keberadaan Posluhdes disebabkan pemahaman petani tentang Posluhdes masih kurang sebagai akibat dari sosialisasi penumbuhan Posluhdes kurang baik dan belum adanya upaya sosialisasi penumbuhan secara mandiri. Belum adanya upaya sosialisasi penumbuhan secara mandiri disebabkan kondisi sekretariat yang sempit dan peralatan masih terbatas. Hal ini juga merupakan penyebab dari masalah perlengkapan administrasi Posluhdes belum ada. Akar permasalahannya adalah alokasi dana Posluhdes yang belum ada.

Masalah struktur organisasi Posluhdes yang tidak mewakili semua komoditi disebabkan oleh belum adanya usulan petani untuk mengembangkan komoditi karena masih belum mengerti fungsi dari keberadaan Posluhdes. Masalah tidak semua petani yang hadir terlibat aktif dalam proses perumusan visi dan misi Posluhdes disebabkan oleh belum disosialisasikan visi dan misi Posluhdes secara baik, sehingga pemahaman petani masih kurang yang bisa jadi disebabkan oleh tingkat pendidikan formal petani relatif rendah. Masalah-masalah Hal ini mempengaruhi kemampuan petani dalam menerima informasi.

Apabila masalah utama Posluhdes belum berjalan sesuai dengan fungsinya, maka programa penyuluhan di tingkat desa tidak dapat disusun sesuai dengan kebutuhan petani di desa. Programa penyuluhan diharapkan dapat menghasilkan penyuluhan pertanian spesifik lokasi yang strategis dan mempunyai daya ungkit terhadap peningkatan produktivitas dan pendapatan petani. Kegiatan yang tercantum dalam programa penyuluhan pertanian akan mampu merespon kebutuhan pelaku utama dan pelaku usaha. 
Tabel 1

Tabel Kesenjangan Penumbuhan dan Penguatan Posluhdes Pattallassang, 2017

\begin{tabular}{|c|c|c|c|}
\hline No. & Fakta & Masalah & Harapan \\
\hline \multicolumn{4}{|c|}{ Aspek Sumberdaya Posluhdes } \\
\hline & $\begin{array}{l}\text { Status lahan milik pribadi oleh ketua } \\
\text { Gapoktan }\end{array}$ & $\begin{array}{l}\text { Status kepemilikan milik } \\
\text { pribadi }\end{array}$ & Status lahan milik Posluhdes \\
\hline 2. & $\begin{array}{l}\text { Bangunan sekretariat Posluhdes } \\
\text { terlihat kurang terawat dikarenakan } \\
\text { usia bangunan tersebut dan jarang } \\
\text { dibersihkan }\end{array}$ & $\begin{array}{l}\text { Kondisi bangunan kurang } \\
\text { terawat } \\
\text { Kondisi sekretariat yang } \\
\text { sempit }\end{array}$ & $\begin{array}{l}\text { Bangunan sekretariat Posluhdes } \\
\text { terlihat rapi }\end{array}$ \\
\hline 3. & Tersedia 35 unit kursi dan 2 unit meja & Peralatan masih terbatas & $\begin{array}{l}\text { Kursi tersedia } 50 \text { unit, } 3 \text { unit } \\
\text { meja dan tersedia lemari buku } \\
\text { dan papan informasi }\end{array}$ \\
\hline \multicolumn{4}{|c|}{ Aspek Kinerja Penumbuhan Posluhdes } \\
\hline & $\begin{array}{l}\text { Penyampaian informasi dari } \\
\text { pengurus Poktan ke anggota } \\
\text { mengenai Posluhdes kurang detail } \\
\text { dan jelas }\end{array}$ & $\begin{array}{l}\text { Pengetahuan petani dari hasil } \\
\text { sosialisasi belum sempurna } \\
\text { Pemahaman petani mengenai } \\
\text { Posluhdes masih kurang }\end{array}$ & $\begin{array}{l}\text { Penyampaian informasi dari } \\
\text { pengurus Poktan ke anggota } \\
\text { mengenai Posluhdes detail dan } \\
\text { jelas }\end{array}$ \\
\hline 5. & $\begin{array}{l}\text { Masih terdapat } 10 \% \text { petani yang } \\
\text { menolak adanya Posluhdes }\end{array}$ & $\begin{array}{l}\text { Masih ada petani yang } \\
\text { menolak pembentukan } \\
\text { Posluhdes }\end{array}$ & $\begin{array}{l}100 \% \text { petani menerima adanya } \\
\text { Posluhdes }\end{array}$ \\
\hline 6. & $\begin{array}{l}\text { Posluhdes belum melakukan upaya } \\
\text { sosialisasi secara mandiri }\end{array}$ & $\begin{array}{l}\text { Belum adanya upaya } \\
\text { sosialisasi penumbuhan } \\
\text { secara mandiri }\end{array}$ & $\begin{array}{l}\text { Posluhdes mampu melakukan } \\
\text { upaya sosialisasi secara mandiri }\end{array}$ \\
\hline \multicolumn{4}{|c|}{ Aspek Kinerja Penguatan Posluhdes } \\
\hline 7. & $\begin{array}{l}\text { Pembukuan, stempel, papan nama } \\
\text { dan papan struktur organisasi belum } \\
\text { ada }\end{array}$ & $\begin{array}{l}\text { Perlengkapan administrasi } \\
\text { organisasi Posluhdes belum } \\
\text { ada }\end{array}$ & $\begin{array}{l}\text { Adanya pembukuan, stempel, } \\
\text { papan nama dan papan struktur } \\
\text { organisasi }\end{array}$ \\
\hline 8. & $\begin{array}{l}17 \text { orang dari } 20 \text { orang petani tidak } \\
\text { aktif dalam proses perumusan visi } \\
\text { dan misi Posluhdes }\end{array}$ & $\begin{array}{l}\text { Tidak semua petani yang } \\
\text { hadir terlibat aktif dalam } \\
\text { proses perumusan visi dan } \\
\text { misi }\end{array}$ & $\begin{array}{l}20 \text { orang petani terlibat aktif } \\
\text { dalam perumusan visi dan misi } \\
\text { posluhdes }\end{array}$ \\
\hline & $\begin{array}{l}\text { Sosialisasi visi dan misi Posluhdes } \\
\text { belum disosialisasikan }\end{array}$ & $\begin{array}{l}\text { Visi dan misi belum } \\
\text { disosialisasikan }\end{array}$ & $\begin{array}{l}\text { Visi dan misi Posluhdes } \\
\text { disosialisasikan }\end{array}$ \\
\hline 10. & $\begin{array}{l}\text { Posluhdes adalah organisasi petani } \\
\text { yang baru sehingga pemahaman } \\
\text { terhadap visi dan misi kurang }\end{array}$ & $\begin{array}{l}\text { Rendahnya pemahaman } \\
\text { petani terhadap visi dan misi } \\
\text { Posluhdes }\end{array}$ & $\begin{array}{l}\text { Semua petani memahami visi } \\
\text { dan misi posluhdes }\end{array}$ \\
\hline & $\begin{array}{l}\text { Posluhdes mengikuti programa } \\
\text { penyuluhan desa yang dibuat oleh } \\
\text { PPL }\end{array}$ & $\begin{array}{l}\text { Programa penyuluhan di } \\
\text { tingka desa belum ada }\end{array}$ & $\begin{array}{l}\text { Programa penyuluhan desa } \\
\text { telah ada }\end{array}$ \\
\hline 12. & $\begin{array}{l}\text { Struktur organisasi posluhdes } \\
\text { mewakili tiga komoditi (padi, jagung } \\
\text { dan nenas) }\end{array}$ & $\begin{array}{l}\text { Strukur organisasi posluhdes } \\
\text { tidak mewakili semua } \\
\text { komoditi }\end{array}$ & $\begin{array}{l}\text { Struktur organisasi mewakili } \\
\text { semua komoditi }\end{array}$ \\
\hline & $\begin{array}{l}\text { Posluhdes belum berfungsi sesuai } \\
\text { amanat UU No. } 16 \text { Tahun } 2006\end{array}$ & $\begin{array}{l}\text { Posluhdes belum berjalan } \\
\text { sesuai fungsinya }\end{array}$ & $\begin{array}{l}\text { Posluhdes berjalan sesuai UU } \\
\text { No. } 16 \text { Tahun } 2006\end{array}$ \\
\hline 14. & Anggaran Posluhdes belum tersedia & $\begin{array}{l}\text { Belum adanya anggaran } \\
\text { Posluhdes }\end{array}$ & $\begin{array}{l}\text { Anggaran yang dimiliki oleh } \\
\text { Posluhdes tersedia }\end{array}$ \\
\hline & $\begin{array}{l}\text { Anggota Posluhdes belum membayar } \\
\text { iuran anggota }\end{array}$ & $\begin{array}{l}\text { Belum adanya alokasi dana } \\
\text { Posluhdes }\end{array}$ & $\begin{array}{l}\text { Anggota posluhdes membayar } \\
\text { iuran anggota }\end{array}$ \\
\hline & $\begin{array}{l}\text { Tidak adanya petani yang } \\
\text { mengusulkan untuk } \\
\text { mengembangkan komoditi pada } \\
\text { struktur organisasi Posluhdes }\end{array}$ & $\begin{array}{l}\text { Belum adanya usulan untuk } \\
\text { mengembangkan komodti } \\
\text { pada struktur organisasi } \\
\text { Posluhdes }\end{array}$ & $\begin{array}{l}\text { adanya petani yang } \\
\text { mengusulkan untuk } \\
\text { mengembangkan komoditi pada } \\
\text { struktur organisasi Posluhdes }\end{array}$ \\
\hline & $\begin{array}{l}\text { Hanya sekitar } 13,23 \% \text { petani yang } \\
\text { memiliki tingkat pendidikan } \\
\text { memadai }\end{array}$ & $\begin{array}{l}\text { Tingkat pendidikan formal } \\
\text { petani relatif rendah }\end{array}$ & $\begin{array}{l}\text { Petani pendidikan yang } \\
\text { memadai }\end{array}$ \\
\hline
\end{tabular}


Hubungan sebab-akibat (kausalitas) antar-masalah sebagaimana yang telah diuraikan secara jelas tergambar dalam struktur pohon masalah sebagaimana ditampilkan pada Gambar 1.

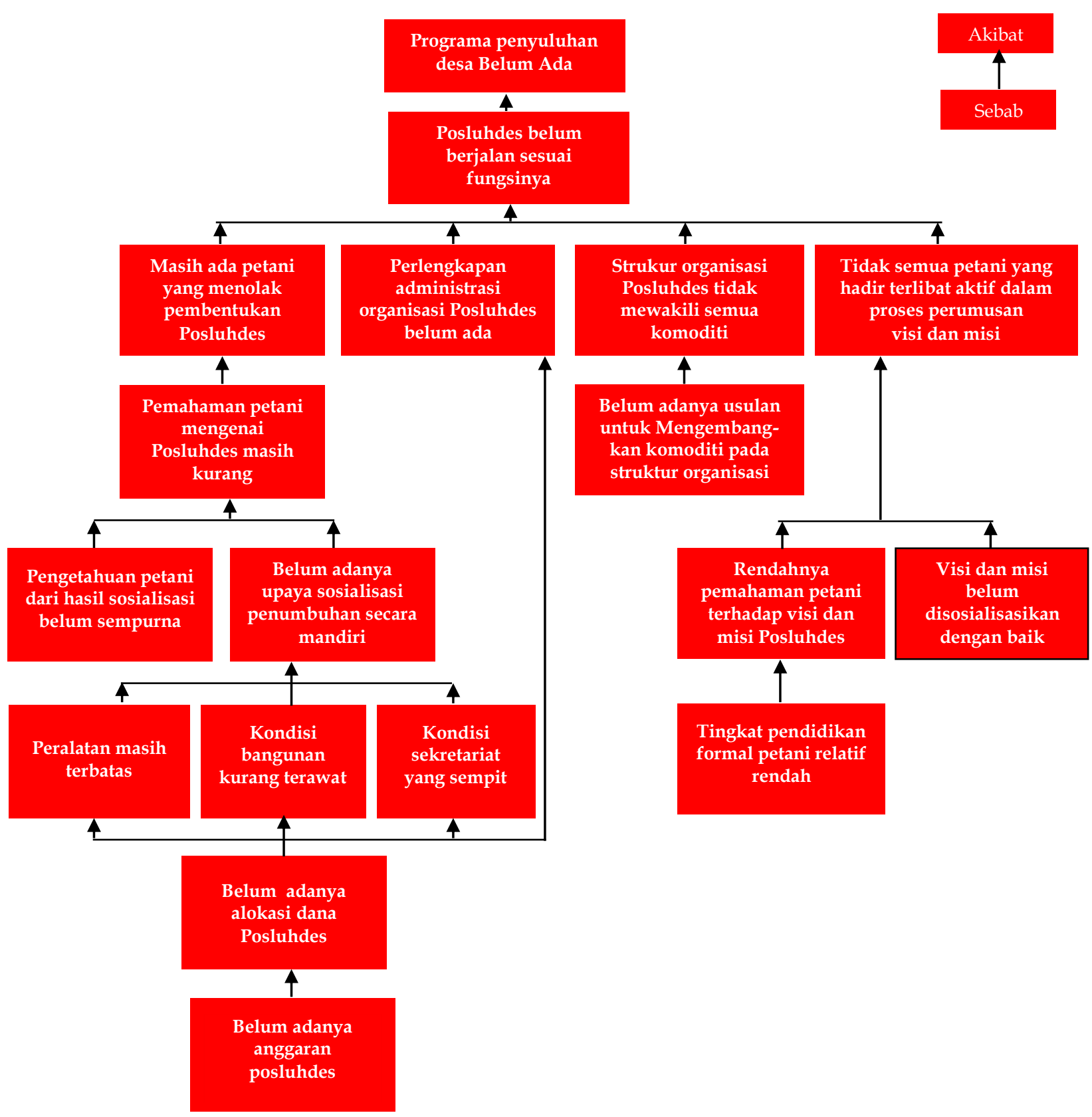

Gambar 1. Diagram Pohon Masalah Pengembangan Posluhdes Pattallassang

\subsection{Sasaran Utama}

Berdasarkan analisis masalah maka sasaran utama yang akan dicapai pada pengembangan Posluhdes adalah Posluhdes berjalan sesuai fungsinya. Sasaran utama ini dapat dicapai jika sasaran-sasaran antara dapat tercapai. Sasaran-sasaran antara tersebut adalah jumlah petani yang menolak adanya Posluhdes berkurang, 
perlengkapan administrasi Posluhdes tersedia, struktur organisasi Posluhdes mewakili semua komoditi dan semua petani yang hadir terlibat aktif dalam perumusan visi dan misi. Jika sasaran utama tercapai, maka akan berdampak pada tersusunnya programa penyuluhan di Desa Pattallassang. Hubungan pencapaian antar-sasaran dalam kegiatan penumbuhan dan pembentukan Posluhdes digambarkan pada diagram pohon sasaran pada Gambar 2.

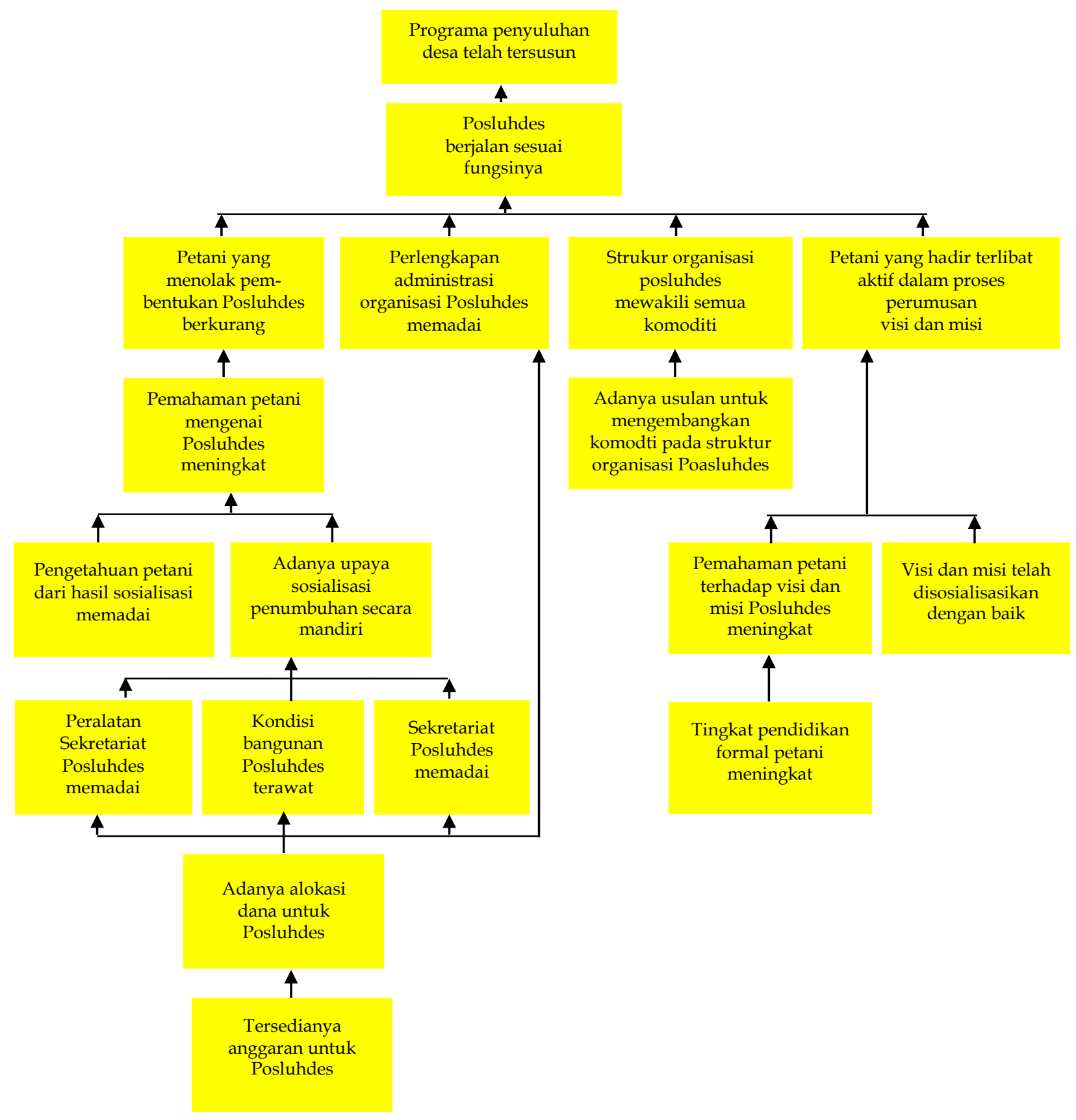

Gambar 2. Diagram Pohon Sasaran Pengembangan Posluhdes Pattallassang 


\subsection{Tindakan Mencapai Sasaran}

Berdasarkan penetapan sasaran dan urutan-urutan pencapaian sasaran sebagaimana tergambar pada Gambar 2, maka dirumuskan tindakan-tindakan untuk dilaksanakan dalam rangka mencapai sasaran antara untuk mencapai sasaran utama pengembangan Posluhdes. Untuk sasaran antara Petani yang menolak pembentukan Posluhdes berkurang ditetapkan tindakan melakukan sosialisasi penumbuhan pada pagi hari, menambah 50 unit kursi pada sekretariat Posluhdes, menambah luas sekretariat Posluhdes dan melakukan pemeliharaan pencegahan untuk gedung sekretariat Posluhdes. Tindakan-tindakan tersebut perlu didahului dengan tindakan penyediaan anggaran untuk kegiatan Posluhdes. Demikian halnya untuk pencapaian sasaran antara Perlengkapan administrasi Posluhdes dapat dicapai apabila dilakukan tindakan penyediaan anggaran untuk kegiatan Posluhdes. Untuk sasaran antara Struktur organisasi Posludes mewakili semua komoditi yang diusahakan di Desa Pattallassang dapat dicapai dengan melakukan tindakan mengembangkan struktur organisasi Posluhdes. Sedangkan sasaran antara Semua petani terlibat aktif dalam proses perumusan visi dan misi Posluhdes dapat dicapai dengan tindakan melakukan sosialisasi visi dan misi Posluhdes. Hubungan antara sasaran utama, sasaran antara dan tindakan-tindakan secara lengkap dapat dilihat pada Gambar 3.

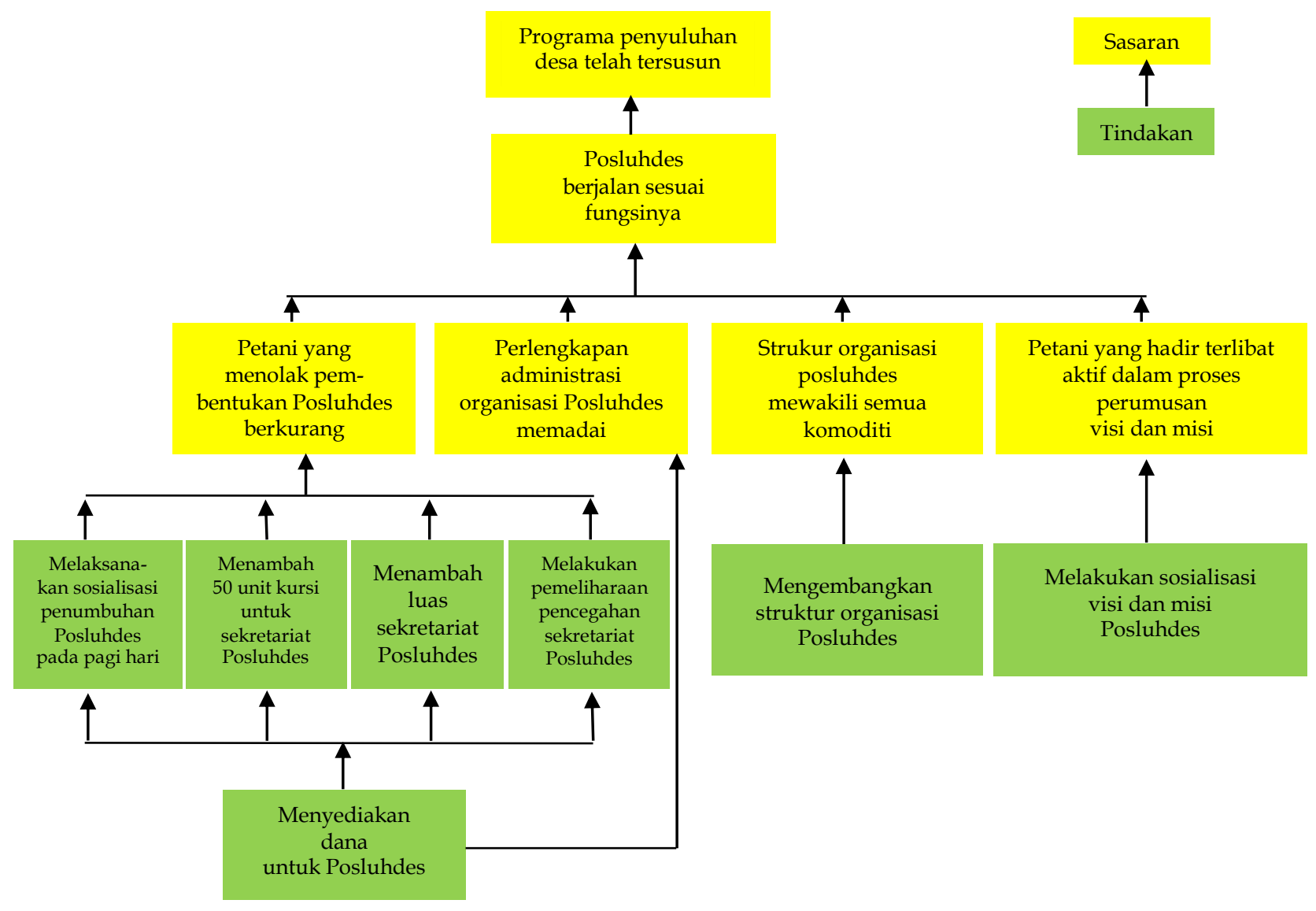

Gambar 3. Diagram Pohon Tindakan Pengembangan Posluhdes Pattallassang 


\section{Kesimpulan}

Berdasarkan hasil analisis masalah yang teridentifikasi dan sasaran yang akan dicapai, maka dirumuskan tindakan dalam rangka pengembangan Posluhdes di Desa Pattallassang, yaitu: melaksanakan sosialisasi penumbuhan Posluhdes pada pagi hasri, menambah 50 unit kursi untuk memenuhi kebutuhan sekretariat Posluhdes, memperluas sekretariat Posluhdes, melakukan pemeliharaan pencegahan bagi sekretariat Posluhdes, mengembangkan struktur organisasi Posluhdes, melakukan sosialisasi visi dan misi Posluhdes serta menyediakan dana yang akan dialokasikan untuk pengembangan Posluhdes.

Pelajaran penting sebagai hikmah bagi peneliti sesuai dengan sasaran belajar yang ditetapkan pada penelitian ini dari aspek pengetahuan adalah manajemen sebagai kunci kesuksesan berkembangnya sebuah agrosistem dalam hal ini agrosistem Posluhdes. Agrosistem yang mampu menerapkan fungsi-fungsi manajemen dalam setiap aktifitasnya serta dalam pemanfaatan sumberdaya yang dimiliki, maka agrosistem tersebut akan berpeluang untuk tumbuh dan berkembang dengan baik. Dari aspek keterampilan diambil hikmah bahwa pemahaman situasi kasus memudahkan untuk menemukan masalah-masalah yang dihadapi oleh Posluhdes dalam penumbuhan dan penguatannya. Pada aspek sikap diambil hikmah bahwa ketidaksetujuan petani terhadap adanya Posluhdes pada dasarnya karena mereka belum memahami fungsi dari Posluhdes sebagai akibat kurangnya sosialisasi yang dilakukan.

\section{Daftar Pustaka}

Al-fattah, H. 2009, Analisis dan Perencanaan Sistem. Jakarta: Bumi Aksara.

Aritonang, 2010. Penyuluhan Pembangunan Pertanian. Surakarta: Sebelas Maret University Press,.

Bapelluh Cilacap, 2015. Penyuluhan Pertanian. Yogyakarta: Kanisius.

Mardikanto, T., 1993. Penyuluhan Pembangunan Pertanian. Surakarta: Sebelas Maret University Press. University Press.

, 2009. Sistem Penyuluhan Pertanian. Surakarta: Sebelas Maret

Van Den Ban, A.W \& H.S, Hawkins, 1999. Penyuluhan Pertanian. Yogyakarta: Kanisius.

Undang-Undang Republik Indonesia Nomor 16 Tahun 2006 Tentang Sistem Penyuluhan Pertanian, Perikanan dan Kehutanan

Marwati, 2015. Penumbuhan dan Pengembangan Posluhdes Sebagai Kelembagaan Penyuluhan Milik Petani. Cyber Extention, Kementerian Pertanian RI. http:/ / cybex.pertanian.go.id/materipenyuluhan/detail/10491/penumbuhandan-pengembangan-posluhdes-sebagai-kelembagaan-penyuluhan-milik-petani 
Pratiwi, N., S. Bulkis, Heliawaty, 2018. Pelaksanaan Programa Penyuluhan Pertanian Di Pos Penyuluhan Desa (Studi Kasus di Desa Layoa, Kecamatan Gantarang Keke, Kabupaten Bantaeng, Provinsi Sulawesi Selatan). http://digilib.unhas.ac.id / uploaded_files Ltemporary/DigitalCollection/ZDIzNjU3MDEwYTU0YTM1NjE5NTcyNWJhOW QzNWFmNjE2NDIzYmIxMA==.pdf. 